\title{
Islamic Microfinance and Rehabilitation Model for the Slum and Floating Population by Waqf Funds, the Case of Bangladesh: A Proposal for Muslim Countries
}

\author{
Basharat Hossain \\ Assistant Professor of Economics \\ Department of Business Administration \\ International Islamic University Chittagong (IIUC), Bangladesh
}

\begin{abstract}
This paper designs a conceptual model of Islamic microfinance and rehabilitation by using the waqf funds for the slum and floating population. It analyzes both the primary and the secondary data on the current status of Islamic microfinance coverage (in thirteen countries), waqf estates (in seven countries), and the slum and floating population in thirty five Muslim countries of the world. The primary data was accumulated on 150 microfinance borrowers and 100 non-borrowers of Bangladesh. This paper presents a multifunctional structure of an autonomous waqf management institution to execute the model of this paper. This institution will be formed by the joint venture of the government, the national, as well as international Islamic agencies. Furthermore, this model will be implemented through five stages, the revival and registration of the waqf estate, accumulation of funds, initiating the Islamic microfinance and rehabilitation for the slum population, and finally, forward linkage that may help the slum people to contribute to the society.
\end{abstract}

Keywords: Waqf, Islamic Microfinance, Rehabilitation, Slum population, Muslim countries.

JEL Classification: G21, O21, Z12

KAUJIE Classification: E23, H15, S4 


\section{Introduction}

The current population of the Muslim world is 1.84 billion which comprises about $24.38 \%$ of the total population of the world (The Royal Islamic Strategic Studies Centre [RISSC], 2017, p. 3). Associated with the Muslim population growth at $1.8 \%$ per year, the urban population in the 51 OIC countries has been increasing tremendously at the rate of $32.90 \%$ between 2005 and 2015 (UN-Habitat, 2015). The main causes of increase in the urban population are the migration of people from village to city for the job, displacement from houses, insecurity, poverty, education, natural disaster, etc. (Gimba \& Kumshe,
2011, p. 171; Bangladesh Bureau of Statistics [BBS], 2015). However, due to the higher cost in urban areas, lower income people choose the slum and shanty for living where the basic rights and services for the citizen are hardly provided by the government or the respective authority. In addition, urban poverty associated with the large number of slum population has been experiencing rapid growth among Muslim countries (Zeinelabdin, 1996, p. 3; Moten, 2005, p. 105; Rahman, 2015). Figure1 shows the comparative scenario between the urban population and the slum population among the Muslim countries.

\section{Figure (1) Urban and the Slum population among the 35 OIC Muslim countries between 2005 and 2020}

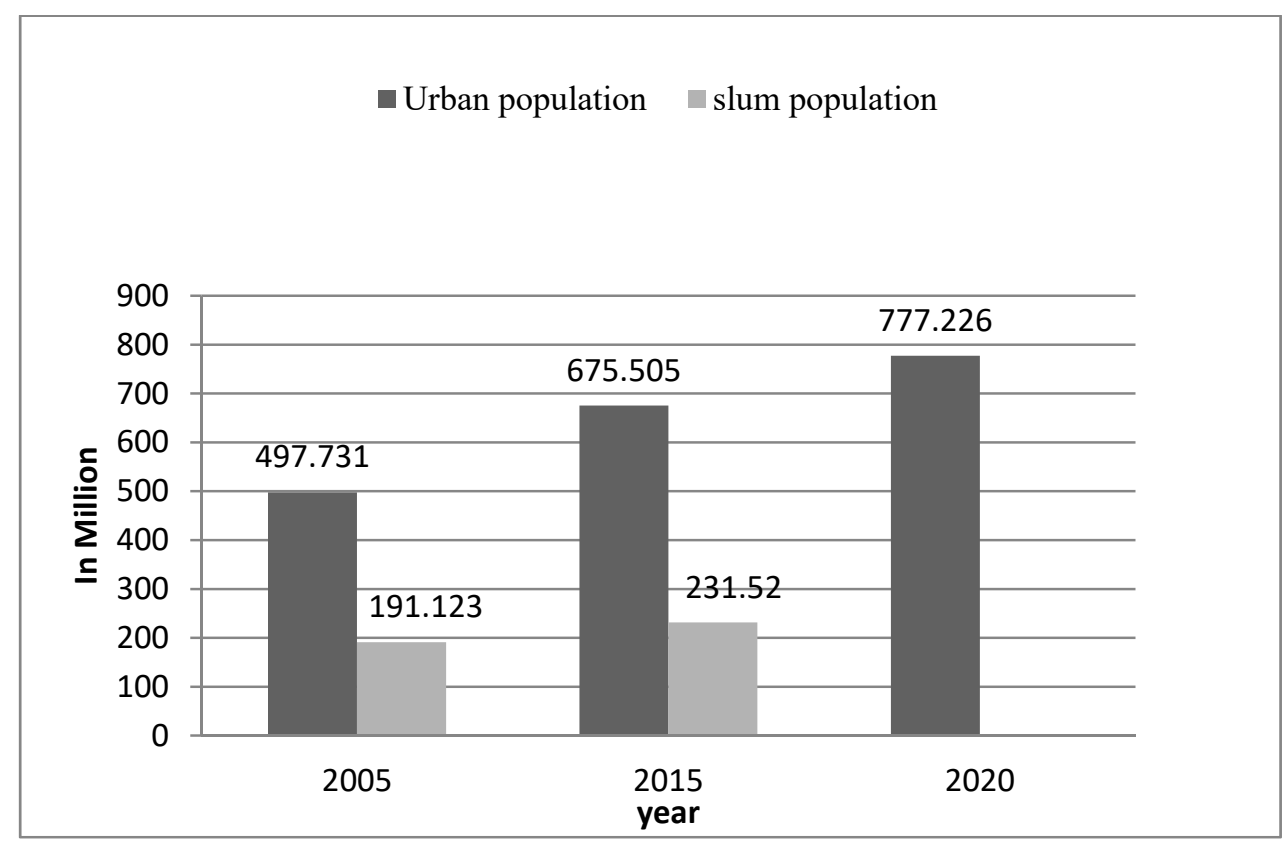

Moreover, the situation has become complex as the formal financial institutions, including banks or investment companies, do not sanction loans or credit for the slum population because of having no collateral. As a consequence, the informal financial institutions, specially microfinance institutions (MFIs) provide microcredit to the slum people. But the MFIs do not approve loans for the extreme urban poor who have no wealth or no tenure security (Taylor, 2013; Hickel, 2015). Consequently, urban poverty still exists and creates a severe problem among the developing countries including the Muslim countries. However, Islam has some first rated charity tools including zakāh, șadaqah, waqf, etc. to solve these problem. In these circumstances, this paper introduces the application of waqf in the Islamic microfinance program. It presents a model of microfinance and rehabilitation for the slum and floating population that can be funded by the waqf. It is proposed that this model be implemented by a joint venture of the government and non-government organizations through an autonomous institution. 
It should be noted that rehabilitation for the slum and floating population is the most important factor, because microfinance without rehabilitation will be totally ineffective and meaningless among the slum and floating population. Without rehabilitation, slum people may consume the microfinance fund instead of investment. The detailed concept of the slum and floating population, the concept and status of Islamic microfinance among the selected Muslim countries, and the concept of urbanization will be discussed below.

This paper comprises of 9 sections. After the introduction, sections 2 and 3 discuss the methodology and literature review. The rationale of the study is presented in section 4. Sections 5, 6 and 7 discuss the status of the Islamic microfinance industry, the waqf industry, and the slum population in the Muslim countries of the world. The proposed model is presented in section 8 . Finally, section 9 provides the conclusion and scope for further research.

\section{Methodology}

The main objective of this paper is to propose a model to initiate the Islamic Microfinance and rehabilitation program by the waqf funds for the slum and the floating population among the Muslim countries. To do so, this paper discusses a descriptive model after analyzing the context of the waqf estates, Islamic microfinance, and the status of slum populations in Muslim countries by using quantitative statistics from both primary and secondary sources.

Primary data was accumulated through a semistructured questionnaire that comprised both openended and close-ended questions. Besides, interviews of microfinance borrowers and observations from visiting the slums were other methods used for data collection. The respondents were selected through systematic random sampling by visiting seven slums of Bangladesh including six slums of Dhaka city, the capital, and one slum of Chittagong city. The data was collected during May-June 2017. The main question was: whether they receive Islamic microfinance or not? What is their eagerness to receive interest free microfinance? Detailed questionnaire is given in the appendix.
Background knowledge and secondary statistics were compiled from different books, articles, reports, brochures, newspapers, and websites of several institutions. The details of the secondary sources are given in the reference section.

\section{Literature Review}

A large number of studies have been performed on waqf, Islamic microfinance, and slum population separately. This section will discuss the relevant studies performed on the topic of this paper.

Mughal (2018) discusses the sources of funding for Islamic microfinance in his article. He proposes to use the waqf fund in Islamic microfinance. Also, Alpay and Haneef (2015, p. 21) in their edited book described an integrated waqf-based Islamic microfinance (IWIM) model for poverty reduction in Malaysia, Indonesia, and Bangladesh. Saad and Anuar (2009, p. 349), in their research, explore the opportunities of cash waqf and Islamic microfinance. Furthermore, Mohamed Ali (2014) presented three models for poverty alleviation integrating zakāh, awqā $f$ and Islamic microfinance.

It should be mentioned that there are many other similar researches available, however, they did not relate the waqf-based Islamic microfinance program with rehabilitation and the slum population. This is the key point upon which this paper focuses, i.e., to present a model for the slum population.

Moreover, this article is distinguished from previous researches in that it investigates the latest scenario of the waqf estates and regulators, the slum population in Muslim countries, and the status of Islamic microfinance in the Muslim world. Besides, it proposes a model to start the Islamic microfinance and rehabilitation program by spending the waqf funds for the slum and floating population in the Muslim countries. This model is a new addition to earlier researches. On the contrary, earlier researches only emphasized separately on waqf and Islamic microfinance. However, they did not present any proposal to use waqf funds for the slum and floating population through the Islamic microfinance program. 


\section{Rationale of the Study}

\subsection{The Rationale for Islamic Microfinance}

The global Islamic finance industry has been growing tremendously during the last 40 years. However, the Islamic microfinance industry contributes only one percent to the overall Islamic finance industry. Moreover, there are more than 2420 microfinance institutions working in the world (Gonzalez, 2008), whereas there are only around 300 Islamic financial institutions, and only about 126 institutions offering Islamic microfinance services (Nimrah, Tarazi, \& Reille, 2008, p. 7; World Bank \& Islamic Development Bank Group, 2016, p. 57). As loan price, conventional or interest-based microfinance institutions charge about 8 percent to 32 percent interest rate while they offer only 6 percent to 8 percent interest on savings (Badruddoza, 2011). Conversely, Islamic microfinance institutions only take nominal profit rate (10-12 percent) and also share the profits as well as losses in their services (Mannan, 2015). Besides, Islamic microfinance institutions also provide buying and selling services as well as interest free loans. Both theory and practice have shown that the superiority of Islamic microfinance is beyond question and that it provides the maximum welfare for its recipients compared to the conventional microfinance institutions.

Moreover, the respondents of the primary survey in this study complained that the interest-based microfinance program has severe problems, including higher interest rate, no loan for the extreme poor, little time for investment, lack of education and training program, and unavailability of the interest free loan. Figures 2, 3, and 4, reveal this information.

Figure (2) Causes of Not Receiving Microfinance by 100 Non-Borrowers

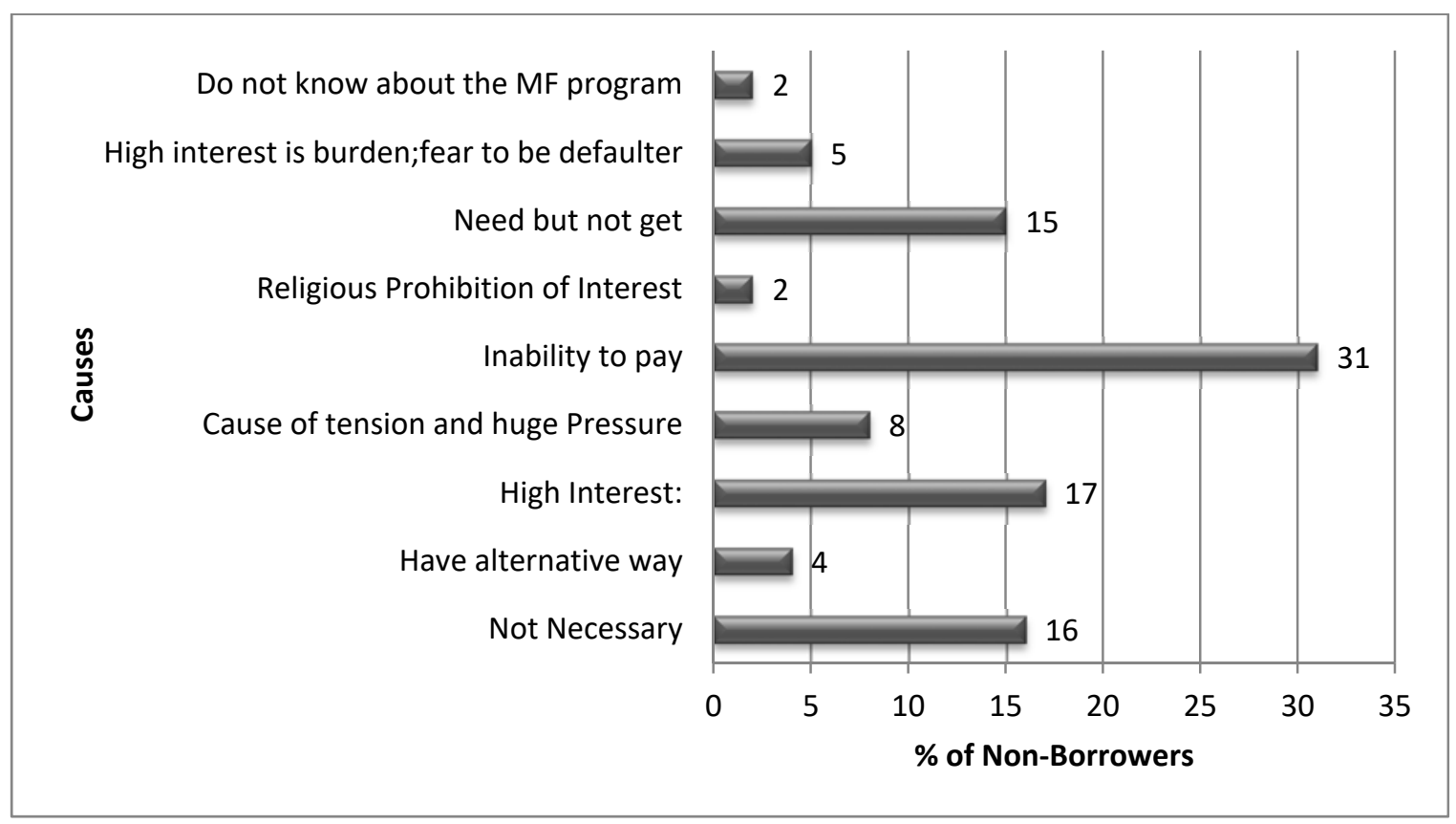


Figure (3) Open Comments of 100 Non-Borrowers about Microfinance and MFIs (\%)

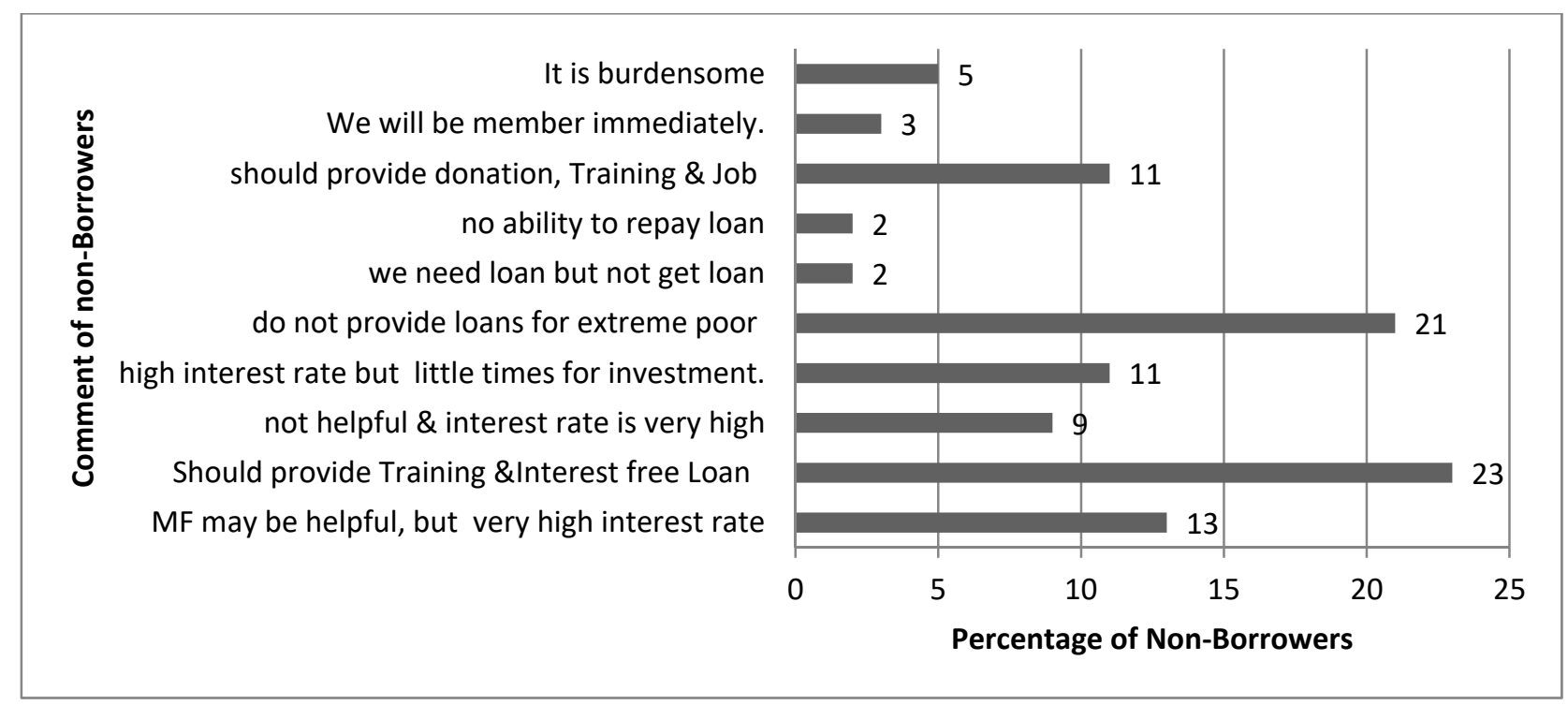

Figure (4) Open Comment of 150 Borrowers about Microfinance and MFIs (\%)

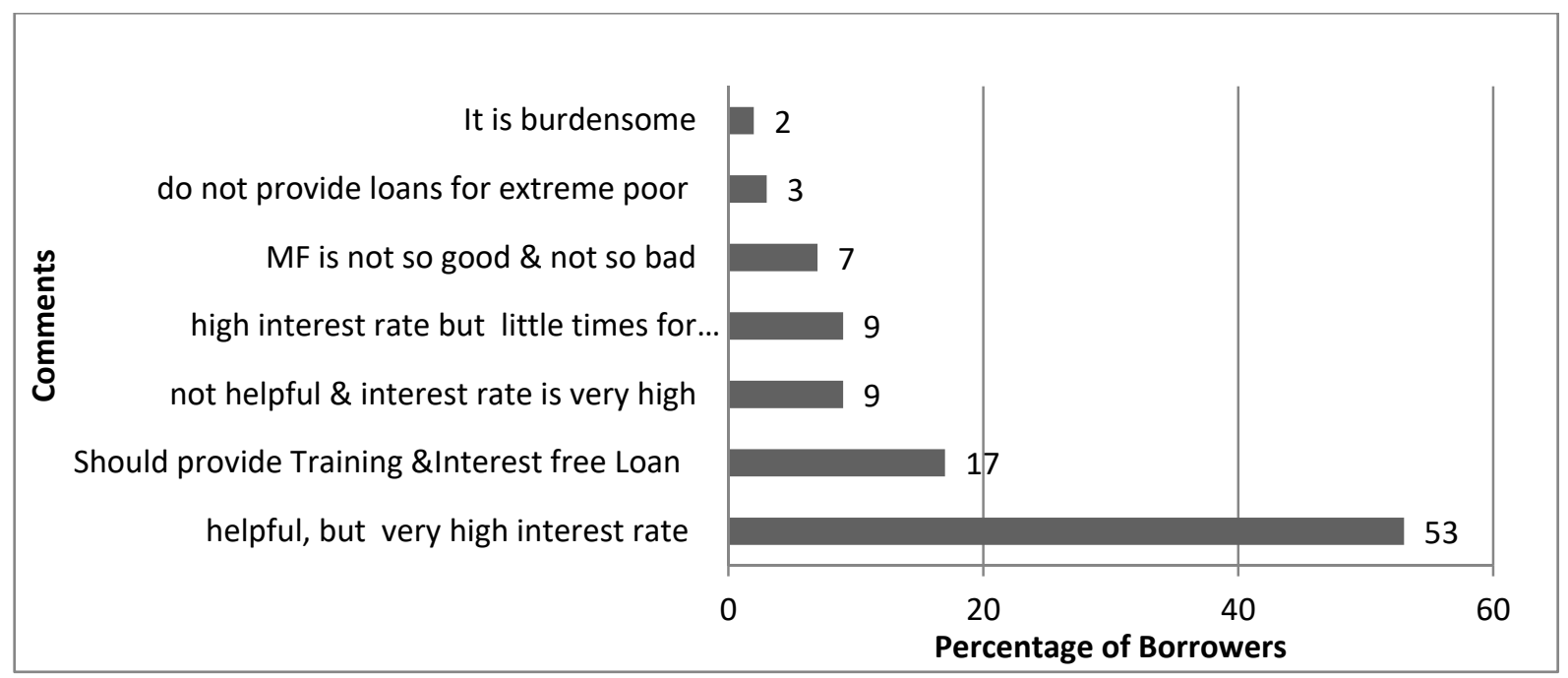

Source: Survey conducted by the author.

Hence, it can be said that, the faults and gaps of the interest-based microfinance program can be filled by the Islamic microfinance program. Also, Islamic microfinance institutions can facilitate the deprived poor of the Muslim world. For this reason, this paper proposes to initiate the microfinance program by the waqf funds.

\subsection{The Rationale for Focusing on The Slum Population}

The slum is the anomaly of urbanization. There are more than 7.5 billion people living in the world (Worldometers, 2018) and about one third of the urban population is living in the slum (World Bank, 2014). Table-1 depicts the scenario of the slum population among the Muslim countries. 
Table (1) The Status of Urban and the Slum Population among the Muslim Countries: 2005-2020

\begin{tabular}{|c|c|c|c|c|c|c|c|}
\hline \multirow[t]{2}{*}{ Country } & \multicolumn{3}{|c|}{$\begin{array}{c}\text { Urban population } \\
\text { (in millions) }\end{array}$} & \multicolumn{2}{|c|}{$\begin{array}{l}\text { Slum population } \\
\text { (in millions) }\end{array}$} & \multicolumn{2}{|c|}{$\begin{array}{c}\% \text { of total urban } \\
\text { population }\end{array}$} \\
\hline & 2005 & 2015 & 2020 & 2005 & 2015 & 2005 & 2014 \\
\hline \multicolumn{8}{|c|}{ Africa } \\
\hline Algeria & 20.80 & 26.41 & 29.19 & - & - & - & - \\
\hline Benin & 3.40 & 5.04 & 6.08 & 2.26 & 2.836 & 71.8 & 61.5 \\
\hline Burkina Faso & 2.56 & 4.23 & 5.42 & 1.762 & 3.327 & 59.5 & 65.8 \\
\hline Cameroon & 9.66 & 13.38 & 15.29 & 4.585 & 4.637 & 47.4 & 37.76 \\
\hline Chad & 2.56 & 4.20 & 5.20 & 2.312 & 2.603 & 91.35 & 88.2 \\
\hline Comoros & .223 & .294 & .343 & .119 & .148 & 68.9 & 69.6 \\
\hline Djibouti & .692 & .852 & .931 & & .449 & & 65.6 \\
\hline Egypt & 31.06 & 37.58 & 41.68 & 5.677 & 3.807 & 17.1 & 10.6 \\
\hline Gabon & 1.08 & 1.31 & 1.42 & .443 & .550 & 38.7 & 37.0 \\
\hline Gambia & & & & .373 & .392 & 45.4 & 34.8 \\
\hline Guinea & 2.97 & 4.37 & 5.37 & 1.390 & 1.913 & 45.7 & 43.3 \\
\hline Guinea-Bissau & .473 & .671 & .825 & .362 & .698 & 83.1 & 82.3 \\
\hline Ivory Coast & - & - & - & - & - & - & - \\
\hline Libya & - & - & - & - & - & - & - \\
\hline Mali & 3.54 & 5.72 & 7.21 & 2.496 & 3.475 & 65.9 & 56.3 \\
\hline Mauritania & 1.20 & 1.62 & 1.89 & & 1.886 & & 79.9 \\
\hline Morocco & 16.76 & 20.76 & 22.07 & 2.205 & 2.619 & 13.1 & 13.1 \\
\hline Mozambique & 7.08 & 10.47 & 12.40 & 5.714 & 6.789 & 79.5 & 80.3 \\
\hline Niger & 2.16 & 3.29 & 4.21 & 1.787 & 2.399 & 82.08 & 70.08 \\
\hline Nigeria & 65.27 & 93.77 & 109.77 & 42.783 & 42.067 & 65.8 & 50.2 \\
\hline Senegal & 4.89 & 6.66 & 7.74 & 2.010 & 2.487 & 43.3 & 39.4 \\
\hline Sierra Leone & 2.06 & 2.80 & 3.32 & 1.824 & 1.857 & 97 & 75.6 \\
\hline Somalia & 2.88 & 4.36 & 5.29 & 2.161 & 3.108 & 73.5 & 73.6 \\
\hline Sudan & 15.04 & 22.51 & 26.61 & - & 11.939 & - & 91.6 \\
\hline Togo & 2.49 & 3.78 & 4.53 & 1.486 & 1.413 & 62.1 & 51.2 \\
\hline Tunisia & 6.60 & 7.76 & 8.34 & - & .593 & - & 8 \\
\hline Uganda & 2.63 & 5.76 & 7.45 & 2.403 & 3.282 & 66.7 & 53.6 \\
\hline \multicolumn{8}{|c|}{ Asia } \\
\hline Afghanistan & 5.74 & 9.63 & 15.36 & - & 5.155 & & 62.7 \\
\hline Azerbaijan & 4.30 & 4.81 & 5.13 & - & - & - & - \\
\hline Bahrain & .641 & .762 & .820 & - & - & - & - \\
\hline Bangladesh & 39.35 & 55.47 & 65.52 & 27.831 & 29.273 & 70.8 & 55.1 \\
\hline Brunei & - & - & - & - & - & - & - \\
\hline Indonesia & 108.83 & 147.20 & 163.85 & 24.777 & 29.212 & 26.26 & 21.8 \\
\hline Iran & 46.47 & 57.05 & 62.38 & & & & \\
\hline Iraq & 18.73 & 23.25 & 26.34 & 9.974 & 11.383 & 52.8 & 47.2 \\
\hline Jordan & 4.34 & 5.47 & 5.96 & .689 & .808 & 15.8 & 12.9 \\
\hline Kazakhstan & 8.69 & 9.82 & 10.41 & - & - & - & - \\
\hline Kuwait & 2.65 & 3.33 & 3.64 & - & - & - & - \\
\hline Kyrgyzstan & 1.86 & 2.20 & 2.42 & - & - & - & - \\
\hline Lebanon & 3.47 & 3.90 & 4.09 & 1.877 & 2.312 & 53.1 & 53.1 \\
\hline Malaysia & 17.34 & 22.76 & 25.13 & - & - & - & - \\
\hline Maldives & .10 & .165 & .20 & - & - & - & - \\
\hline Oman & 1.79 & 2.21 & 2.45 & - & - & - & - \\
\hline Pakistan & 55.13 & 75.60 & 89.07 & 27.158 & 32.265 & 47.5 & 45.5 \\
\hline Palestine & - & - & - & - & - & - & - \\
\hline Qatar & .76 & .92 & 1 & - & - & - & - \\
\hline Saudi Arabia & 19.12 & 24.33 & 27.02 & 3.442 & 4.384 & 18 & 18 \\
\hline
\end{tabular}




\begin{tabular}{|c|c|c|c|c|c|c|c|}
\hline \multirow[t]{2}{*}{ Country } & \multicolumn{3}{|c|}{$\begin{array}{l}\text { Urban population } \\
\text { (in millions) }\end{array}$} & \multicolumn{2}{|c|}{$\begin{array}{l}\text { Slum population } \\
\text { (in millions) }\end{array}$} & \multicolumn{2}{|c|}{$\begin{array}{c}\% \text { of total urban } \\
\text { population }\end{array}$} \\
\hline & 2005 & 2015 & 2020 & 2005 & 2015 & 2005 & 2014 \\
\hline Syria & - & - & - & 1.080 & 2.429 & 10.5 & 19.3 \\
\hline Tajikistan & 1.73 & 2.11 & - & - & - & - & - \\
\hline Turkey & 49.10 & 59.02 & 63.66 & 7.422 & 6.578 & 15.5 & 11.9 \\
\hline Turkmenistan & 2.29 & 2.85 & 3.29 & - & - & - & - \\
\hline United Arab Emirates & 3.19 & 4.15 & 4.62 & - & - & - & - \\
\hline Uzbekistan & 9.76 & 11.66 & 12.99 & - & - & - & - \\
\hline Yemen & 6.10 & 9.87 & 12.37 & 4.088 & 5.166 & 67.2 & 60.8 \\
\hline \multicolumn{8}{|c|}{ Europe } \\
\hline Albania & 1.41 & 1.71 & 1.86 & - & - & - & - \\
\hline \multicolumn{8}{|c|}{ South America } \\
\hline Guyana & .209 & .211 & .218 & .073 & .076 & 33.7 & 33.1 \\
\hline Suriname & .334 & .367 & .379 & .013 & .026 & 3.9 & 7.3 \\
\hline
\end{tabular}

Source: Compiled by the author from: (UN-Habitat, 2015).

According to the report of the UN, in 2015, on average, 46.25 percent of the urban population was residing in the slum areas of 32 Muslim countries in Asia and Africa (UN-Habitat, 2015). Also, almost all of the urban poor live in the slum of the cities. Unfortunately, the combined coverage of Islamic microfinance institutions in rural and urban areas is very little compared to the conventional microfinance institutions. More precisely, the coverage in the urban areas is totally dissatisfactory and meagerly mentionable. On the other hand, it is a matter of great hope that according to a report on the results from nine different surveys on the poor of Pakistan,
Jordan, Syria, Palestine, Algeria, Yemen, and Indonesia, on average, approximately $40 \%$ of potential Muslim borrowers preferred Islamic microfinance over interest-based microfinance facilities (Mughal, 2017).

Considering the miserable condition of Islamic microfinance among the slum population, we collected primary data by conducting a survey on several slums of Dhaka and Chittagong cities of Bangladesh. Table-2 shows that, among the seven slums and about two hundred and fifty respondents, only two respondents in a slum received the Islamic microfinance services.

Table (2) The Coverage of Islamic MFIs among the slums in Bangladesh

\begin{tabular}{llccccc}
\hline $\begin{array}{c}\text { City of } \\
\text { Bangladesh }\end{array}$ & Name of the slum & $\begin{array}{c}\text { Slum } \\
\text { Population }\end{array}$ & $\begin{array}{c}\text { Coverage of } \\
\text { total MFIs in } \\
\text { the slum }\end{array}$ & $\begin{array}{c}\text { Borrower } \\
\text { Respondents }\end{array}$ & $\begin{array}{c}\text { Non- } \\
\text { Borrower } \\
\text { Respondents }\end{array}$ & $\begin{array}{c}\text { Coverage of } \\
\text { Islamic MFIs } \\
\text { in the slum }\end{array}$ \\
\hline Dhaka & $\begin{array}{l}\text { Juraine Rail line slum } \\
\text { Gendaria Rail line } \\
\text { slum }\end{array}$ & 5,000 & 3 & 10 & 10 & 0 \\
& $\begin{array}{l}\text { Kamalapur Rail line } \\
\text { slum }\end{array}$ & 10,000 & 6 & 20 & 10 & 2 (IBBL) \\
& $\begin{array}{l}\text { Malibag Rail line } \\
\text { slum }\end{array}$ & 12,000 & 4 & 10 & 10 & 0 \\
& $\begin{array}{l}\text { Khilgaon Rail line } \\
\text { slum }\end{array}$ & 500 & 0 & 10 & 10 & 0 \\
& $\begin{array}{l}\text { Korail slum } \\
\text { Khalpar slum, Ba- } \\
\text { haddar hat }\end{array}$ & 80,000 & 15 & 40 & 10 & 0 \\
\multicolumn{1}{c}{$\mathbf{7}$} & 5,000 & 3 & 50 & 20 & 0 \\
\hline Thittagong & & $\mathbf{3 4}$ & $\mathbf{1 5 0}$ & $\mathbf{1 0 0}$ & $\mathbf{2}$ \\
\hline Sotal & &
\end{tabular}

Source: Compiled by the author. 
Moreover, $62 \%$ of borrowers and $22 \%$ of nonborrowers indicated higher interest rate as one of the main problems of microfinance. Also, $93 \%$ of nonborrowers and $98 \%$ of borrowers expressed their eagerness to become members of an Islamic microfinance institution if it provides interest-free loan, and education and training facilities (as can be seen from Figures 5 and 6 ). For this reason, this paper suggests to initiate Islamic microfinance among the slum population in the Muslim countries.

Figure (5) Comments of 100 Non-Borrowers on Islamic Microfinance

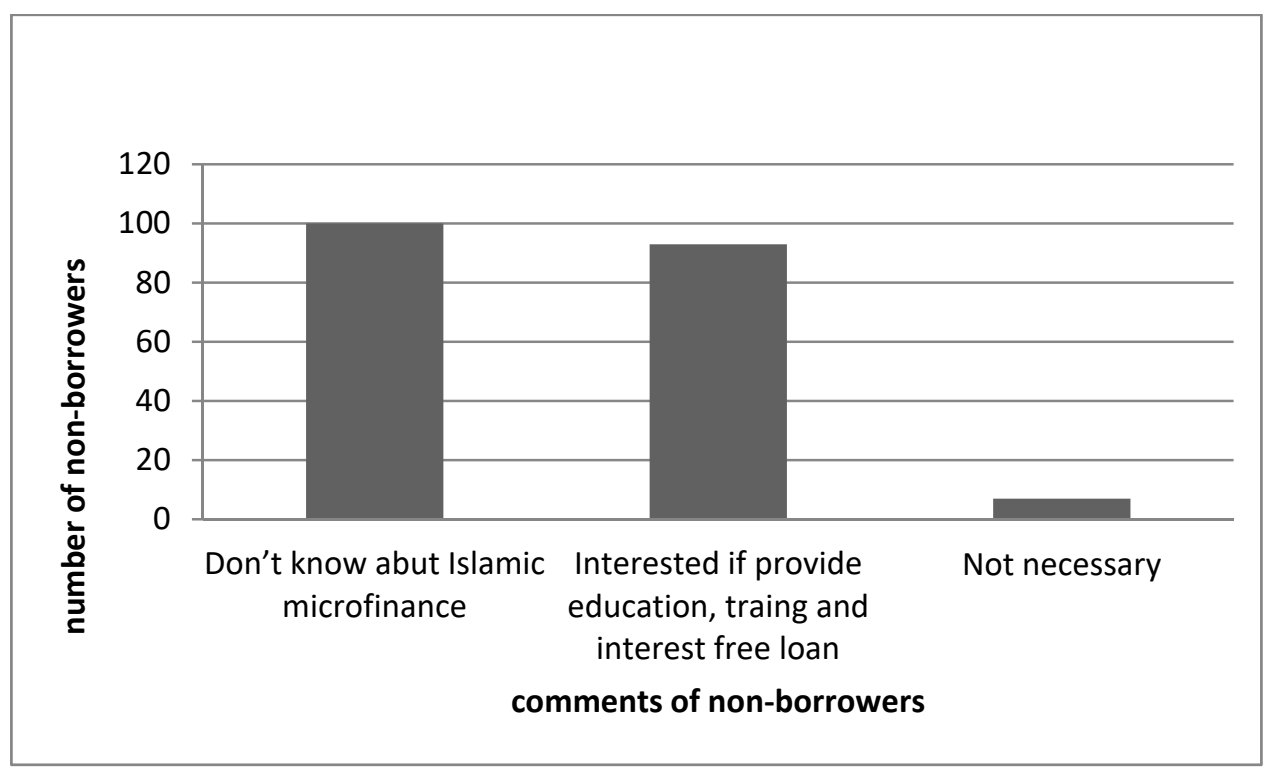

Figure (6) Comments of 150 Borrowers on Islamic Microfinance

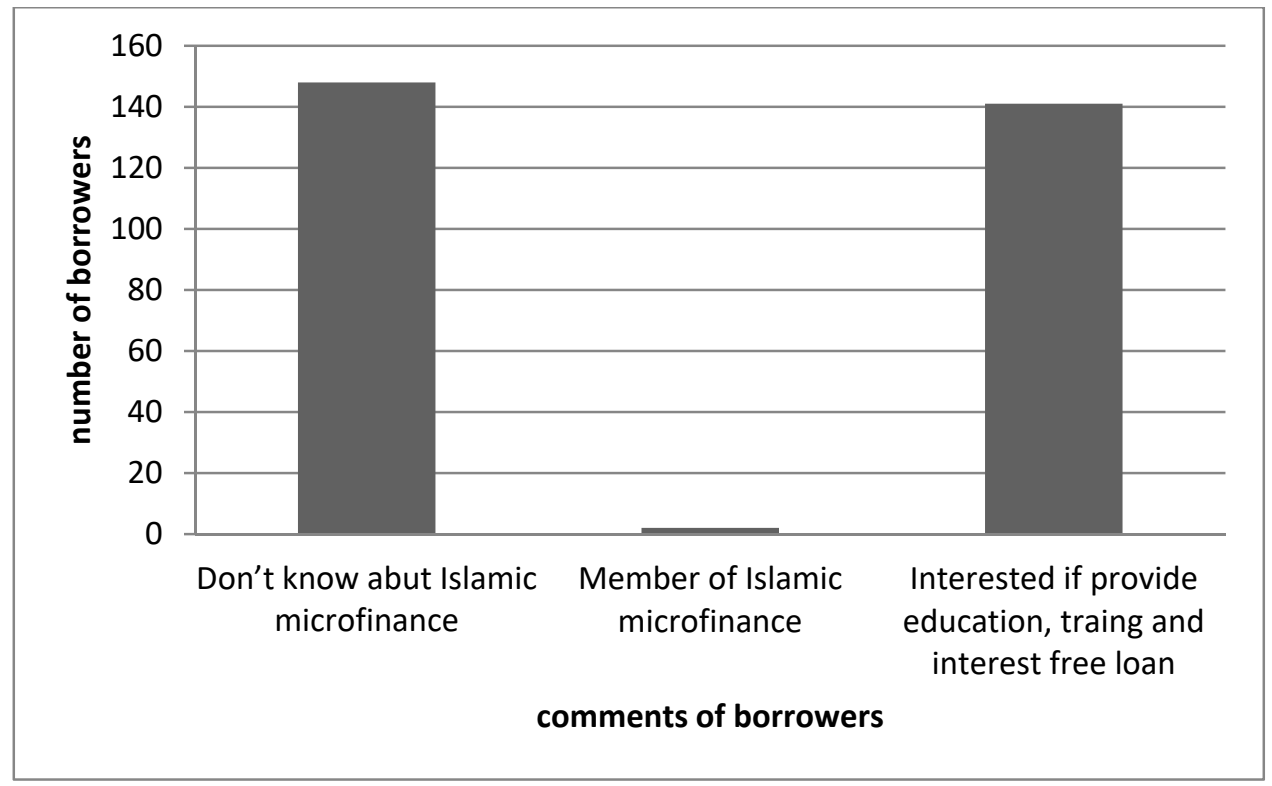

Source: Survey conducted by the author. 


\subsection{The Rationale for Using Waqf as the Instrument of Islamic Microfinance}

Islam has the best tools to eradicate the poverty of the extremely poor people. Zakāh and șadaqah are currently being used for alleviating poverty through multi-dimensional projects such as the zakāh-based group lending and microfinance program by elzawa in Indonesia (Sudirman, 2016; http://elzawa.uinmalang.ac.id), the zakāh-based group investment for the family by the center for zakāh management in Bangladesh (CZM, 2019), the zakāh-based community program in Brunei Darussalam (Jaelani, 2016), and many more. Waqf is another instrument of Islam for public and family welfare. The inherent goal of this paper is to revive the waqf through its multidimensional usage in Muslim countries, much like $z a k a \bar{h}$ is being used. The investment of waqf funds in the microfinance program can also be another source of income for the waqf estates. This paper initiates these issues by presenting a model.

\section{Nature, Services, and Status of Islamic Microfinance in the World}

Microfinance consists of financial and non-financial services. Financial services are: microcredit, microsavings, and micro-insurance products. The nonfinancial services offer healthcare services, education, skills and training program, enterprise development, development of self-confidence, marketing and management capabilities, and women empowerment (Ledgerwood, 1998, p. 1; Lendwithcare, 2019).

It should be mentioned that, the concept of modern microfinance was introduced by the Nobel Prize laureate economist, Muhammad Yunus in 1976 by establishing 'Grameen Bank' (Yunus \& Jolis, 2006, p. 5). It should also be noted that, unfortunately, it was based on interest. However, modern Islamic microfinance started in Iran in 1967. It was known as qard hasan fund that was used to provide interest free loans for marriage, providing trousseau, cure diseases, house repairing, educational subsidies, and subsidies for rural housing and for other needs (Bakhtiari, 2009 , p. 102). However, modern microfinance is run on the principles of interest or usury, while Islamic microfinance is operated on the principles of profitloss sharing and interest free loans.

According to the nature of the services, there are two kinds of services that are available in the Islamic microfinance program. The first one is the profitable services and second one is the non-profitable services (which may have some nominal fee). Profitable services are mainly concentrated on those Islamic modes of investments that are profitable in nature. For instance, mud̄̄rabah, mushārakah, murābahah, and bay" salam. On the other hand, non-profitable services are mainly concentrated on the qard hasan (benevolent loan) mode of investment (Asutay, 2010, p. 25).

Furthermore, Islamic microfinance institutions provide both financial and nonfinancial products and services for its members. Table- 3 gives a list of some products and services of Islamic microfinance institutions. The funds of Islamic microfinance are accumulated from the capital of MFIs, lending, or charity, like zakāh, sadaqah, and waqf (Mughal, 2018). The most common Islamic modes of investment employed in Islamic microfinance industry are muräbahah, bay' mu'ajjal, ijārah, bay' salam, qard hasan, mud̄ārabah, and mushārakah (Dar \& Azmi, 2017).

Table (3) Products and Services of Islamic Microfinance Institutions

\begin{tabular}{|c|c|}
\hline Financial & Non-financial \\
\hline Microcredit; Micro savings; & Health Services: Medical Camp, Circumcision Camp, \\
\hline Micro-insurance (takāful) & Medical Assistance, Welfare Gift \\
\hline Small industry: Handicraft & $\begin{array}{l}\text { Education: Award \& Scholarship, Distribution of educa- } \\
\text { tional materials program, religious education }\end{array}$ \\
\hline qarḍ hasan & Training \\
\hline Poultry/Bird and Livestock Fisheries & Environment: Nursery/Forestry; Plantation program \\
\hline Agro-based products: Crops & - \\
\hline Relief \& Rehabilitation & - \\
\hline Transport buying & - \\
\hline Housing equipment & - \\
\hline
\end{tabular}

Source: (Mannan, 2015), compiled by the author. 
The current size of the global Islamic finance industry was about $\$ 2.43$ trillion at the end of 2017 (Dar \& Azmi, 2017) and it is forecasted to reach around $\$ 4.362$ trillion by the end of 2020 (World Bank, 2018a; Dar \& Azmi, 2017). Also, the assets of the global Islamic finance industry increased by $280.28 \%$ during the 2007-2017 period and the average growth rate was 17.82 percent for the same period (Dar \& Azmi, 2017). Moreover, there are more than 1500 Islamic financial institutions which are functioning in the world, out of which about 300 institutions provide Islamic microfinance services in 32 countries of the world (Mughal, 2017). The current size of the Islamic microfinance industry is about 1 billion USD (Mughal, 2017) which contributes about 1 percent of the market share to the total Islamic finance market in the world (Dar \& Azmi, 2017). Moreover, Most of the Islamic microfinance institutions are concentrated in the East Asia and Pacific region (64\%) followed by the Middle East and North Africa region (28\%) (Nimrah et al., 2008; Dar \& Azmi, 2017). Islamic microfinance institutions have been growing at a rate of around 20 percent. Table-4 reveals the latest status of Islamic microfinance in the world.

Table (4) The Status of Islamic Microfinance in the World

\begin{tabular}{|c|c|c|c|c|c|}
\hline Country & Year & $\begin{array}{l}\text { No. of } \\
\text { Islamic } \\
\text { MFIs } \\
\text { (IMFIs) } \\
\end{array}$ & $\begin{array}{l}\text { No. of } \\
\text { Total } \\
\text { MFIs }\end{array}$ & $\begin{array}{l}\text { Share in } \\
\text { the } \\
\text { market }\end{array}$ & Name of well-known Islamic MFIs \\
\hline Afghanistan & 2017 & 1 & 14 & - & $\begin{array}{l}\text { FINCA, WOCCU, Ariana Financial Services, IFIC, } \\
\text { Islamic Relief }\end{array}$ \\
\hline Bangladesh & 2018 & 8 & 707 & $1 \%$ & $\begin{array}{l}\text { Islami Bank Bangladesh Limited (IBBL), Muslim } \\
\text { Aid Bangladesh, Islamic relief Bangladesh }\end{array}$ \\
\hline Indonesia & 2007 & 105 & 64000 & - & $\begin{array}{l}\text { BPRS, Islamic Financial Cooperatives referred to as } \\
\text { Bait Maal wat Tamwil (BMT) }\end{array}$ \\
\hline Iraq & 2017 & 6 & 14 & $10 \%$ & Al Takadum, \\
\hline Pakistan & 2018 & 15 & 31 & $0.9 \%$ & $\begin{array}{l}\text { Akhuwat, Islamic Relief Pakistan (IRP), Farz Foun- } \\
\text { dation, ASASAH, Muslim Aid, CWCD, HHRD, } \\
\text { NRSP, NRDP, Naymet }\end{array}$ \\
\hline Yemen & 2017 & 2 & 12 & - & $\begin{array}{l}\text { Al-Hudaidah, Al Amal Microfinance Bank, Al Ku- } \\
\text { rumi Microfinance }\end{array}$ \\
\hline Syria & 2017 & - & - & - & Sanadiq project, Jabal al Hoss \\
\hline Sudan & 2017 & $\begin{array}{c}7 \\
9 \text { banks }\end{array}$ & 7 & - & - \\
\hline Malaysia & 2017 & 2 & - & - & AIM and Bank Rakyat, Amina Iftikhar, Tabung Haji \\
\hline Iran & 2008 & 7000 & 7000 & & Qard al-Hasan Fund \\
\hline Maldives & 2017 & 1 & - & - & \\
\hline Bahrain & 2017 & 1 & 2 & - & Family Bank \\
\hline Algeria & 2017 & 1 & - & - & \\
\hline
\end{tabular}

Source: compiled by the author from (MRA, 2018; https://bit.ly/2NEqzwV; https://bit.ly/2G0hsQL; http://www.micraindo.org; Alshebami, 2017; Bakhtiari, 2009; CBB, 2017; Mughal; 2017)

It should be mentioned here that, unfortunately, there are no latest compiled statistics and survey reports on the Islamic microfinance industry available in the world. Most of the data are incomplete and insufficient for research.

The performance of the Islamic microfinance industry is quite satisfying in several Muslim countries around the world. For instance, the performance of
FINCA in Afghanistan, the Rural development scheme (RDS) of Islami bank Bangladesh Limited (IBBL) in Bangladesh, Akhawat and Wasil foundations in Pakistan are particularly mentionable. The participation of women varies from 60 percent to 80 percent and the average recovery rate is 99 percent (Mannan, 2015). 


\section{A discussion on the Concept of Waqf and Waqf Institutions in Muslim Countries}

\subsection{Cash Waqf}

At present cash waqf is practiced among several Muslim countries of the modern world including, Saudi Arabia, Malaysia, United Arab Emirates, Oman, Bangladesh, Kuwait, etc. (Ahmad, 2015). Besides, Islamic financial institutions (including bank and non-bank financial institutions), make use of the cash waqf through investment projects. The mudāarabah cash waqf account is most common among the Islamic banks and Islamic non-bank financial institutions in Bangladesh and many other Muslim countries of the world. In Bangladesh, the profit of cash waqf has been spent for the rehabilitation of the destitute family, health, education, culture, and social utility services (https://bit.ly/2XwL51U). Table-5 illustrates this scenario.

\subsection{Waqf Administration and Number of Waqf Institutions in Muslim Countries}

It should be mentioned that, most of the waqf institutions are supervised and administered by the ministry of religious affairs of the Muslim countries. The exact data on waqf assets and institutions are not available for all Muslim countries. However, table- 6 presents the information regarding the waqf authority and the number of waqf institutions in Muslim countries.

Table (5) Implementation of Cash Waqf in the World

\begin{tabular}{|c|c|c|}
\hline Country & Institution & Cash Waqf Account \\
\hline Bangladesh & Islami bank Bangladesh Limited & Mudāarabah Cash Waqf deposit account (https://bit.ly/2XwL51U) \\
\hline Bangladesh & Al-Arafah Islami bank Limited & $\begin{array}{l}\text { Mudāarabah Cash Waqf deposit scheme (https://www.al- } \\
\text { arafahbank.com/CWD.php) }\end{array}$ \\
\hline Bangladesh & EXIM bank & $\begin{array}{l}\text { Mud̄ārabah Cash Waqf Deposit (MCWD) } \\
\text { (https://bit.ly/2YGV9Ha) }\end{array}$ \\
\hline Bangladesh & Social Islami bank Limited & Cash Waqf Deposit, (https://bit.ly/2YMaMNL) \\
\hline Bangladesh & Shahjalal Isla & Mudāarabah Cash Waqf Deposit (https://bit.ly/2LFjdX9) \\
\hline Bangladesh & First Security Islami bank Limited & Mudāarabah Cash Wakf Deposit Scheme_(https://bit.ly/2Xvnhka) \\
\hline Bangladesh & $\begin{array}{l}\text { Islamic Finance and Investment } \\
\text { Limited }\end{array}$ & Mudārabah Cash Waqf Deposit Scheme (https://bit.ly/2Xuyrkb) \\
\hline Malaysia & May bank & Waqf solution by Maybank Islamic (https://bit.ly/2NxO2Q3) \\
\hline Saudi Arabia & Alinma Investment Company & Alinma Wareef $W a q f$ Fund ("Saudi Arabia's first ...", 2018) \\
\hline
\end{tabular}

Source: Compiled by the author from the websites of the respective institutions.

Table (6) Waqf Authority and Number of Waqf Institutions in Muslim Countries

\begin{tabular}{|c|c|c|c|}
\hline Country & Waqf Authority & $\begin{array}{c}\text { Number of Waqf Institutions/Value } \\
\text { of the Waqf Asset }\end{array}$ & $\begin{array}{c}\text { Annual contribution to Na- } \\
\text { tional Waqf Fund }\end{array}$ \\
\hline Bangladesh & $\begin{array}{l}\text { Ministry of Reli- } \\
\text { gious Affairs }\end{array}$ & $\begin{array}{c}20536 \\
(2014-15)\end{array}$ & BDT 58.67 million \\
\hline Pakistan & $\begin{array}{l}\text { Ministry of Reli- } \\
\text { gious Affairs }\end{array}$ & - & - \\
\hline Malaysia & - & $\begin{array}{c}9937 \text { hectares of Waqf land worth } \\
\text { RM1.9 billion }\end{array}$ & - \\
\hline Indonesia & $\begin{array}{l}\text { Ministry of Reli- } \\
\text { gious Affairs }\end{array}$ & $\begin{array}{c}\text { Waqf land } \\
4.2 \text { million meters }\end{array}$ & - \\
\hline Turkey & & 9000 & \\
\hline Yemen & Ministry of Waqf & $10-15 \%$ land & - \\
\hline Jordan & Ministry of Waqf & 10000 & $\begin{array}{c}\text { JOD } 0.94 \text { million } \\
(1998)\end{array}$ \\
\hline
\end{tabular}

Source: Compiled by the author from (GOB, 2016) and from other sources. 


\section{A Discussion on the Concept of Slum, Slum Population, and Urban Population in Muslim Countries}

A slum refers to the extremely congested housing units where 5 to 25 households live. It is characterized by crowdy, unhealthy environment with inadequate water and sanitation facilities, built upon public or private land with inadequate tenure security. The slum households usually work in the informal sectors (CUS-NIPORT \& MEASURE Evaluation , 2006).

It should be noted that, between 2005 and 2015, with the growth of urbanization, the number of slum populations increased by $11.29 \%$ among the 32 Muslim countries. More precisely, the rate of increase in the slum population is higher among 9 Asian and 2 South American Muslim countries (14.29\%), compared to the 20 African Muslim countries (7.44 \%). Actually, it is not urbanization but may be called as slumization. Because the data revealed that, among the 32 Muslim countries, on average, $46.25 \%$ of the urban population was living in the slum areas in 2015. This figure is $32.16 \%$ and $54.71 \%$ for 9 Asian and 20 African Muslim countries respectively (UNHabitat, 2015). The latest status of the slum population in Muslim countries has already been discussed above (see table-1).

\section{The Proposed Islamic Microfinance and Rehabilitation Model for the Slum and Floating Population by Waqf Funds}

\subsection{The Model Framework}

This section presents the structure of the model (Figure-7) and discusses the implementation method of the model. The aim of this model is to initiate the Islamic microfinance and rehabilitation program for the slum and floating population with the waqf funds.

The reason for proposing this model is that in most of the Muslim countries the waqf estates are operated and managed under the ministry of religious affairs (see table-6). Consequently, the waqf estates get the same concentration as other (large number of) programs or activities under the ministry of religious affairs, such as the development of religious institutions, training for the imāms of mosques, publication of Islamic books, zakāh collection, etc. (GOB, 2018). Besides, the ministry only preserves and maintains the waqf estates. On the other hand, this model emphasizes on the multi-dimensional usage of the waqf estate through the microfinance programs to alleviate the poverty of the slum and floating population. 
Figure (7) The Schematic Presentation of the Model

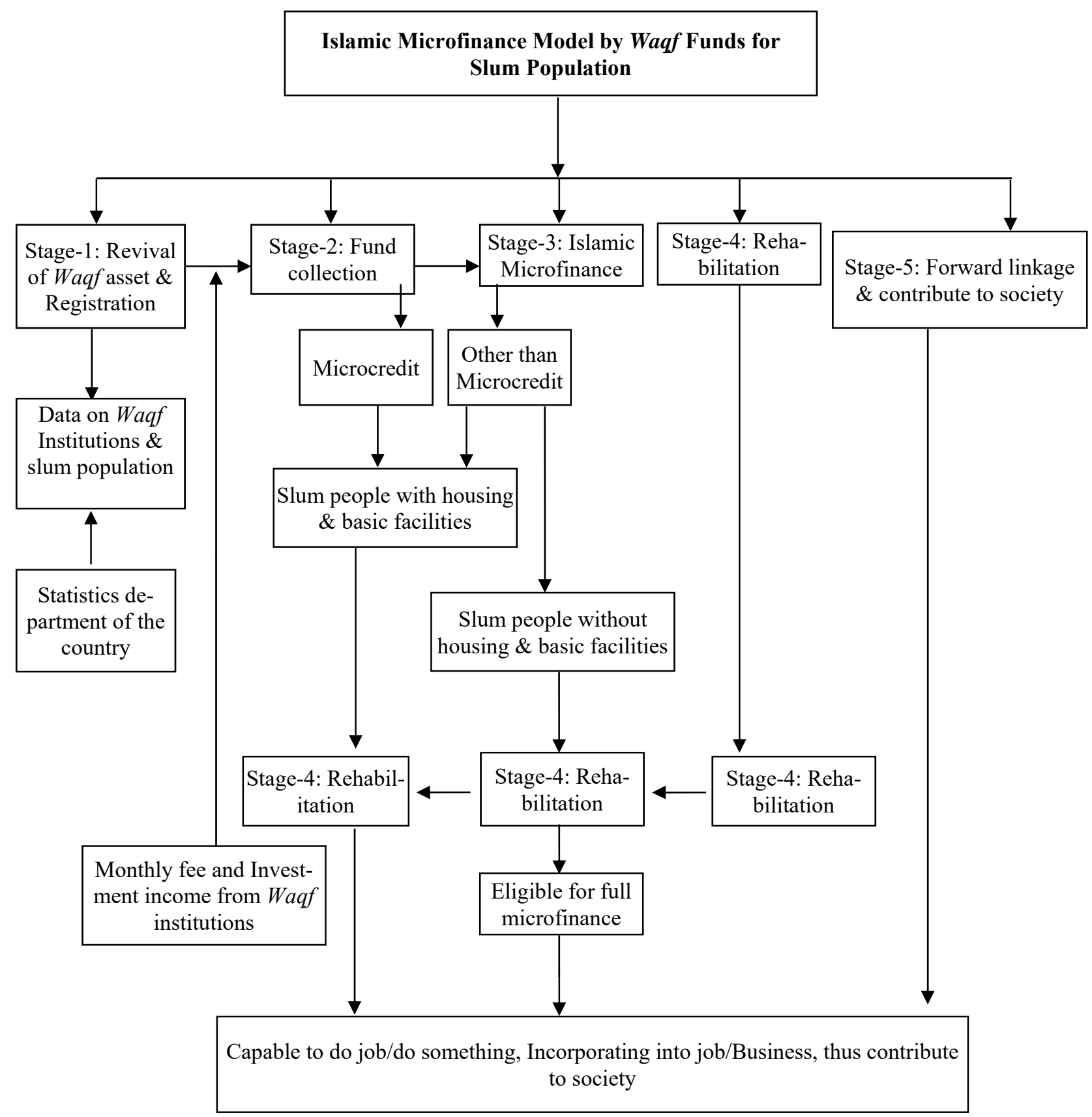


This model will be implemented by the formation of an independent and autonomous institution through the following five stages:

Stage-1: Revival and registration of the waqf estate and institution: This stage will ensure the registration of the waqf asset in the respective country.

Stage-2: Fund Accumulation: This stage will design the sources and processes of collecting funds from the waqf institutions.

Stage-3: Islamic microfinance by the waqf fund: This stage will start the Islamic microfinance program by using the waqf fund.

Stage-4: Rehabilitation of the slum people by the waqf fund: This stage will make the plan of rehabilitation and execute the rehabilitation program for the slum and floating population.

Stage-5: Slum people contribute to the society: This stage will introduce the way that may help the slum people to engage and contribute to the society.

\subsection{Implementation of the Model}

To implement this model, the responsible institution will be formed by the joint venture of the government and private Islamic authority. It must be an independent and autonomous institution (may be called the Waqf Management Authority) that will be formed by the joint committee from the government of the respective country and the national as well as international Islamic institutions (such as the Islamic Development Bank [IDB]). The idea of the joint venture between the government and the private authority is taken from the concept of public-private partnership (PPP) projects. PPP can be defined as a long-run agreement between a private and public authority to manage a project of the government by the private entity by using the public assets. The private authority must bear the operational risk and accountability, and they will be rewarded by the level of output or performance (World Bank, 2018b). Since, both private and public waqf estates are available in the Muslim world, hence, a waqf management institution cannot be run without government support. This is why this model follows the public-private partnership (PPP) idea. There are a large number of evidences available on the joint venture project between the government and the private authority in different countries, including Bangladesh, Pakistan, Saudi Arabia, and many other Muslim countries (GOB, 2019; GOP, 2010; http://pppsaudi.com/).

\subsection{Waqf Management Authority (WMA) and Its Functions}

The Waqf Management Authority (WMA) will be responsible to raise the funds and execute the model. To run the functions smoothly and properly, national as well as international Islamic institutions and the government authority will provide the manpower, logistic support, and also monitor its activities. The accumulated fund will be added to the Central Waqf Fund (CWF). The final disbursement and accomplishment will be run by the WMA. This paper suggests the 'multifunctional structure' for the WMA that is given in figure-8. The multifunctional structure of an organization can be defined as a structure where an organization performs its operations through several functional departments by centralized controlling (Brooks, 2006, p. 184). This institution will have five departments to implement the goals and the five stages of the model.

Figure (8) The Schematic Presentation of the Structure of the The Waqf Management Authority (WMA)

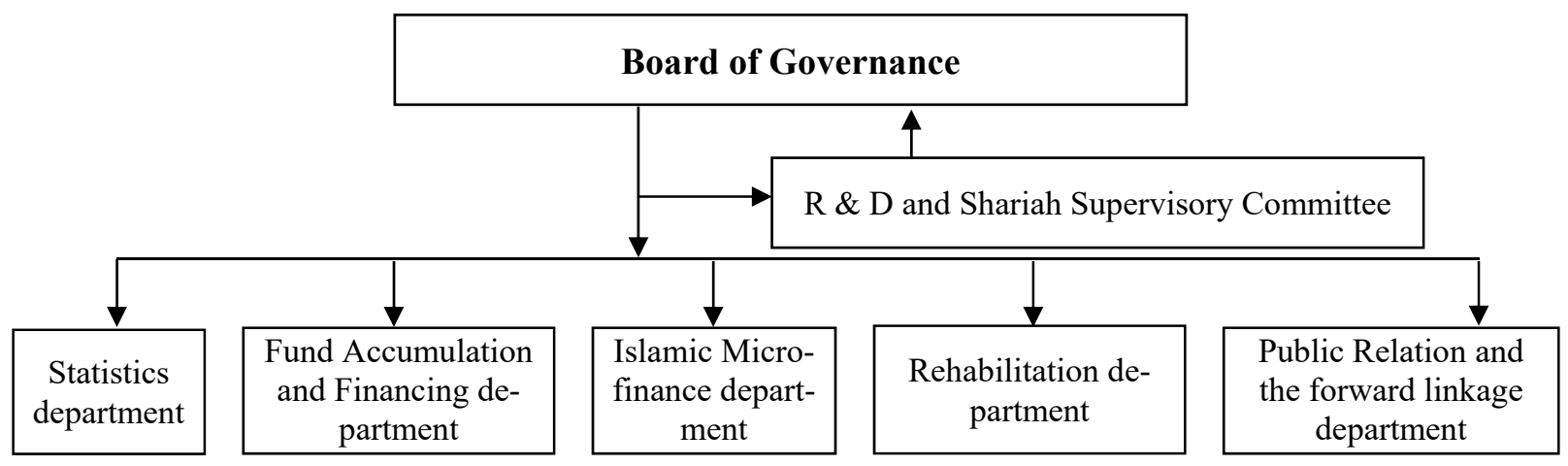


The board of governance will be formed by members from the national as well as international Islamic institutions and the government authority. The Shari'ah supervisory committee will be formed by approval of the board of governance. The Shari'ah supervisory committee will be responsible for the Shar1'ah audit, guiding the waqf-based projects to strictly follow the Sharīah guidelines, and research and development such as innovation of new ideas on the multi-dimensional usage of the waqf. Moreover, the board of governance will not take any decision on any project unless and until it is approved by the Shar'1 ah supervisory committee. Besides, this institution will have five departments:
a. Statistics Department
b. Fund Accumulation and Financing Department
c. Islamic Microfinance Department
d. Rehabilitation Department
e. Public Relation and the Forward Linkage Department

\section{a. Statistics Department}

The statistics department will fulfill the goal of the first stage. The statistics department will have two functions. The first function is to collect the data on the waqf estates and waqf institutions in the respective country. In most of the countries, the ministry of religious affairs collects data and supervises the waqf institutions (table-6). The second function is to collect the data on the number of slums, slum population, floating population, and landless slum population in the respective country. In addition, it has to collect the data on the number of microfinance recipients, slum people eager to become members of Islamic microfinance institutions, educational and occupational status of the slum people, etc. Usually, the national statistics divisions, waqf authority, and the microfinance regulatory authority collect and preserve these data. This department may take help from these respective offices.

Figure (9) Functions of the Statistics Department

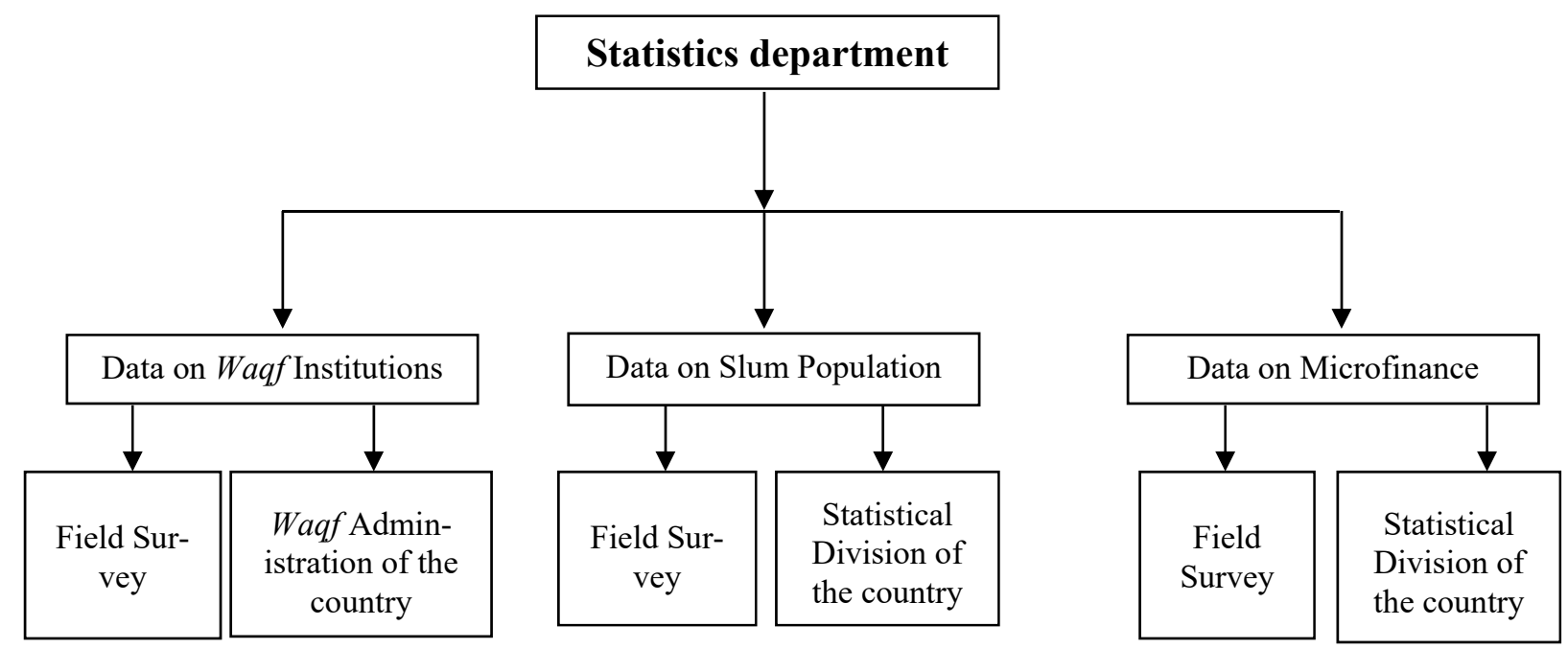

\section{b. Fund Accumulation and Financing Department}

The fund accumulation department will achieve the objective of the second stage. This department will be responsible to collect the funds from the respective country and international agency. The statistics department will help the fund accumulation department by providing relevant data and information. Funding can be accumulated through integrating income and contributions from the waqf estates and institutions. The detailed sources of funding are given below: 
Figure (10) Sources of Funding for the Central Waqf Fund

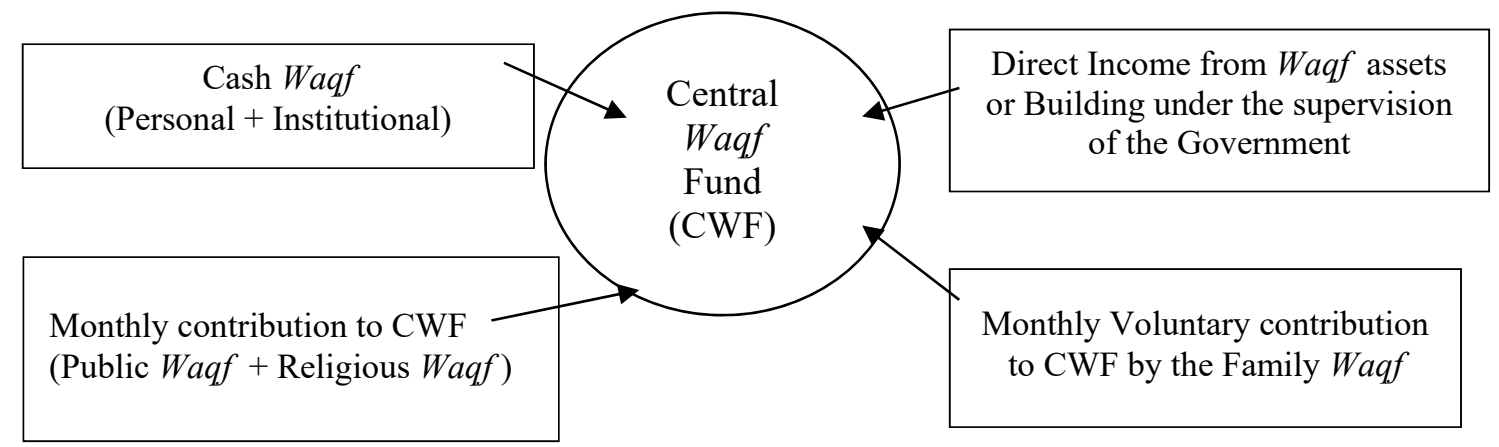

Cash Waqf (Personal + Institutional): The fund from cash waqf may be collected from the person who is willing to donate his waqf funds. In addition, this fund may be raised by the financial institutions such as the waqf account in Islamic banks, and Islamic non-bank financial institutions. The investment procedure of cash waqf has already been discussed (see section 6.1 above).

Monthly Contribution to the CWF (Public Waqf + Religious Waqf): The waqf administration of Bangladesh imposes a compulsory fee or contribution on the waqf estates and institutions. The yearly contribution was BDT 56.87 million in 2017. In Bangladesh, about 1.392 million waqf estates are waiting to be registered. Such kind of waqf fee may be introduced to raise the waqf funds in other countries as well.

Direct Income from the Waqf Asset or Building: The investment income from the waqf assets under the supervision of the government will also be included in this fund.

Monthly Voluntary Contribution to the CWF (Family Waqf): It would not be wise to impose any fee on family waqf institutions. However, the CWF may receive any voluntary donation from the family waqf estates and institutions.

\section{c. Islamic Microfinance Department}

The Islamic microfinance department will implement the goal of the third stage. The key functions of this department are to innovate and execute the Islamic microfinance services to the slum and floating population. To determine the targeted slum and floating people for the Islamic microfinance program, the nature and characteristics, and the housing and residential status of the slum people should be explored. For this purpose, it should be mentioned that, there are two kinds or groups of the slum people. The first group lives in rented government or private land and they have some basic facilities of water, sanitation, and electricity. In contrast, the second group lives in vacant government land or the land adjacent to the rail line, etc., and have no facilities of water, sanitation, and electricity.

The first group may be qualified for the fullfledged Islamic microfinance services including microcredit investment. After becoming the members of the Islamic microfinance program, they will be rehabilitated gradually. On the contrary, the second group should be rehabilitated first and then they may become the members of the full-fledged Islamic microfinance services including microcredit investment. But they may be the recipients of services (education, health care, etc.) of Islamic microfinance rather than the microcredit investment.

In addition, the policy for the second group may also be applied to the floating population who live on the footpath or roadside and rehabilitate them in the same way.

Moreover, the Islamic microfinance program should provide the primary services of water, sanitation, education, health care, training and skill development, for the slum and floating population, and then it may offer the microcredit services for the floating population. 


\section{d. Rehabilitation Department}

The rehabilitation department will fulfill the goal of the fourth stage. The rehabilitation department will have two functions. The first function is to rehabilitate the landless slum people who have lost their houses due to river erosion or any other reason and have migrated from the villages. The land for rehabilitation may be acquired or bought by the WMA with the help of the government. The houses will be constructed with the help of the international Islamic institutions under the supervision of the WMA. The rehabilitation department will design or form the different family units. Each unit may consist of five families and rehabilitate them gradually. The rehabilitated family will have to pay a nominal rent for the housing unit. This rent will be added to the central waqf fund (CWF). The number of the units and families may be fixed based upon the availability of the fund. Besides, this department will educate them about the future prospects of their life. The second function of the department will be to rehabilitate the floating poor who live on the footpath or roadside and rehabilitate them in the same way as mentioned in the first function.

\section{e. Public Relation and the Forward Linkage Department}

The public relation and the forward linkage department will accomplish the goal of the fifth stage. The main function of this department is to develop relationships with several institutions, centers, companies, firms, industries, etc., where it can incorporate the microfinance members as trainees for part-time or full time jobs. Besides, it may create linkage with the local and international market and agencies to sell the handicraft products (for example) which are produced by the microfinance borrowers.

This department may develop linkages with several sectors. These sectors may include garment industries, security companies, shopping centers, educational institutions, home service companies, financial institutions, small and medium enterprises (SME), non-government organizations (NGOs), and development agencies.

Examples of some positions that can be filled by the microfinance members which require minimal education are, third or fourth class workers such as a peon, bearer, workers in motor repairing and washing center, electronic product making and repair centers for refrigerators, televisions, computers, mobile servicing, salesmanship, tailoring, etc. Furthermore, affiliations with different institutions will train and make the participant capable for the job. In this way, he/she will become capable to contribute to the society.

\section{Summary and Conclusion}

Islam has several first-rated charity tools for public welfare and the alleviation of poverty. Besides zakāh and șadaqah, waqf is another superb instrument that is considered as a religious will - a gift of personal property by will. This paper presented a model to start the Islamic microfinance and rehabilitation program by spending the waqf funds for the slum and floating population in Muslim countries. This paper has been prepared by collecting both the primary and secondary data. The proposed model will be accomplished by establishing an independent and autonomous waqf management institution by a joint venture of the government of the respective country and the national as well as international Islamic agency such as the Islamic Development Bank (IDB). Likewise, this model will be executed through five stages, which are: the revival and registration of the waqf estate, accumulation of funds, introducing the Islamic microfinance program, rehabilitation for the slum people, and forward linkage that may help the slum people to engage in the job market and contribute to the society. It is high time to reduce the burden of the slum population among the Muslim countries, because the tremendous growth of the slum population warns the Muslim countries about the upcoming hazard in urbanization. Hence, any kind of policy failure in managing this problem may create severe difficulties in the Muslim world.

\subsection{Scope for Further Research}

The application of waqf in Islamic microfinance is an extensive field of research. This article only highlighted the topic that how to use the waqf funds for the slum population. In addition, the waqf estates can also be used for charitable investment fund, which is another strong tool for sustainable development. Further studies may be done on the multi-dimensional uses of waqf in Islamic economics and finance. 


\section{References}

Ahmad, M. (2015). Cash Waqf: Historical Evolution, Nature and Role as an Alternative to Riba-Based Financing for the Grass Root. Journal of Islamic Finance, 4(1), 63-74.

Ali, M. K. (2014). Integrating Zakah, Awqaf and Islamic Microfinance for Poverty Alleviation: Three Models Of Islamic Micro Finance (IRTI Working Paper Series No. WP\# 1435-19). Retrieved from: https://bit.ly/2RZjDbZ

Alpay, S., \& Haneef, M. A. (Eds.). (2015). Integration of waqf and islamic Microfinance for poverty reduction: Case Studies of Malaysia, Indonesia and Bangladesh. Kuala Lumpur, Malaysia: The Statistical, Economic and Social Research and Training Centre for Islamic Countries (SESRIC) and International Islamic University Malaysia (IIUM).

Alshebami, A. S., \& Rengarajan, V. (2017). Microfinance Institutions in Yemen: "Hurdles and Remedies". International Journal of Social Work, 4(1), 10-21.

Al-Tasuli, A. I. (1998). Al-Bahjah Fi Sharh al-Tuhfah: edited by Muhammad AbdulQadir Shahun,. v.2,369, Lebanon: Dar Al-Kutub Al-Ilmiyyah

Asutay, M. (2010). Islamic Microfinance: Fulfilling Social and Developmental Expectations. In Islamic finance: instruments and markets (pp. 25-30). London, UK: Bloomsbury Information.

Badruddoza, S. (2011). Microfinance in Bangladesh: Red and Green Lights [PowerPoint slides].Retrieved from: https://bit.ly/2NFdROm

Bakhtiari, S. (2009). Islamic Microfinance, Providing Credit to the Poor: A Case Study of Iran. International Economics Studies, 34(1), 99-107.

Bangladesh Bureau of Statistics [BBS]. (2015). Preliminary Report on Census of Slum Areas and Floating Population 2014. Retrieved from: https://bit.ly/30rd2KL

Brooks, I. (2006). Organisational Behaviour: Individuals, Groups and Organisation (3rd ed.). London, UK: Financial Times Prentice Hall.

Center for Zakat Management [CZM]. (2019). JEEBIKA - Livelihood Development. Retrieved from: http://czm-bd.org/jeebika

Centre for Urban Studies [CUS], National Institute of Population Research and Training [NIPORT], \& MEASURE Evaluation. (2006). Slums of urban Bangladesh: Mapping and Census 2005. Dhaka, Bangladesh: Authors. Retrieved from: https://bit.ly/30bGrs6
Dar, H., \& Azmi, S. (Eds.). (2017). Global Islamic Finance Report 2017. London, UK: Edbiz Consulting. Retrieved from: http://www.gifr.net/gifr_2017.htm

Gimba, Z., \& Kumshe, M. G. (2011). Causes and effects of rural-urban migration in borno state: a case study of maiduguri metropolis. Asian Journal of Business and Management Sciences, 1(1), 168-172.

Gonzalez, A. (2008). How Many Borrowers and Microfinance Institutions (MFIs) Exist? Microfinance Information Exchange [MIX]. Retrieved from: https://bit.ly/2Jjbk8w

Government of Bangladesh [GOB], Ministry of Religious Affairs [MORA]. (2018, October 15). Project Contacts. Retrieved from: https://bit.ly/2JlIUL7

Government of Bangladesh [GOB], Office of the Administrator of Waqfs. (2016). Annual report. Retrieved from: https://bit.ly/2FYweay

Government of Bangladesh [GOB], Public Private Partnership Authority Bangladesh [PPPA]. (2019, June 26). PPP Projects. Retrieved from: https://pppo.gov.bd/projects.php

Government of Pakistan [GOP], Public Private Partnership Authority [PPPA]. (2010). Pakistan Policy on Public Private Partnerships: Private Participation in Infrastructure for Better Public Services. Retrieved from: www.ipdf.gov.pk/prod_img/PPP Policy FINAL 14May-2010.pdf

Hickel, J. (2015, June 10). The microfinance delusion: who really wins? The Guardian. Retrieved from: https://bit.ly/2aLhuP4

Jaelani, A. (2016). Zakah Management for Poverty Alleviation in Indonesia and Brunei Darussalam. Turkish Economic Review, 3(3), 495-512.

Ledgerwood, J. (1998). Microfinance hand book: an institutional and financial perspective. Washington, USA: The World Bank.

Lendwithcare. (2019). About Microfinance. Retrieved from: https://lendwithcare.org/info/about-us/aboutmicrofinance

Mannan, M. A. (2015). Islamic Microfinance: Bangladesh Experience [PowerPoint slides]. Retrieved from: https://bit.ly/2RZkae4

Microcredit Regulatory Authority [MRA]. (2018). List of Licensed MFIs as of 27 May, 2018. Retrieved from: https://bit.ly/2XNRaLB 
Moten, A. R. (2005). Poverty in the Muslim World and Communities: Causes and Solutions. Intellectual discourse, 13(1), 103-107.

Mughal, M. Z. (2017). Islamic Agri \& Rural Finance [PowerPoint slides]. Retrieved from: https://bit.ly/2Ju0afM

Mughal, M. Z. (2018). Funding Sources for Islamic Microfinance Institutions. Retrieved from: http://www.alhudacibe.com/imhd/news43.php

Nimrah, K., Tarazi, M., \& Reille, X. (2008). Islamic Microfinance: An Emerging Market Niche (Focus Note 49, Consultative Group to Assist the Poor [CGAP]). Retrieved from: https://bit.ly/2NMiJB8

Rahman, K. (2015, January 29). Poverty \& Underdevelopment in the Muslim World (Part 1). Retrieved from: https://bit.ly/3105uib

Saad, N. M., \& Azizah, A. (2009). Cash waqf and Islamic microfinance: Untapped economic opportunities. Islam and Civilisational Renewal [ICR], 1(2), 337-354.

Saudi Arabia's first waqf investment fund launched. (2018, September 5). Arab news. Retrieved from: https://bit.ly/2SLE7pf

Sudirman, M. A. (2016). Implementing "Zakat"-Based Microfinance in Indonesia. IOSR Journal of Economics and Finance [IOSR-JEF], 7(5), ver. II, 57-61.

Taylor, S. (2013). Microfinance and Extreme Poverty: Why the Extreme Poor are Left Out? (Honours Thesis, University of Victoria, Victoria, Canada). Retrieved from: https://bit.ly/2Ko3SZ5
The Royal Islamic Strategic Studies Centre [RISSC]. (2017). The Muslim 500: The World's 500 Most Influential Muslims - 2018. Amman, Jordan: Author. Retrieved from: https://bit.ly/2ZobBww

UN-Habitat. (2015). Global Urban Indicators Database 2015. Retrieved from: https://bit.ly/2XwTC5d

World Bank, \& Islamic Development Bank Group. (2016). Global Report on Islamic Finance: Islamic finance - A Catalyst for Shared Prosperity. Washington, USA: Author.

World Bank. (2014). Population living in slums (\% of urban population). Retrieved from: https://bit.ly/32ZN2I7

World Bank. (2018a). Islamic Finance Bulletin, Issue 33. Retrieved from: https://bit.ly/2FWx1Jc

World Bank. (2018b, February 6). What Are PublicPrivate Partnerships? Retrieved from: https://bit.ly/2psK7VV

Worldometers. (2018). Current World Population. Retrieved from: https://bit.ly/Ism9T6

Yunus, M., \& Jolis, A. (2006). Banker to the Poor: The Autobiography of Muhammad Yunus, Founder of Grameen Bank. London, UK: Oxford University Press.

Zeinelabdin, A. R. (1996). Poverty in OIC countries: status, determinants and agenda for action. Journal of economic cooperation among Islamic countries, 17(34), 1-40. 


\section{Appendix}

\section{QUESTIONNAIRE}

Islamic Microfinance Survey in the Slum areas of Bangladesh-2017 Proliferation of Islamic Microfinance in Bangladesh

Note: I ensure that, this survey data will be used only for academic purposes, these are confidential and will never be used for commercial purposes. Respondents are safe and will never face any difficulties with data.

\begin{tabular}{|c|c|c|}
\hline \multicolumn{3}{|c|}{ Section-1: Household Information Roster } \\
\hline 1.Household ID & \multicolumn{2}{|c|}{ 0. Non-borrower $\quad$ 1. Borrower } \\
\hline \multicolumn{3}{|l|}{ 1.1.Name of Respondent: } \\
\hline 1.2.Gender of Respondent: & \multicolumn{2}{|c|}{$\begin{array}{ll}\text { 1. Men } & \text { 2. Women }\end{array}$} \\
\hline \multicolumn{3}{|l|}{ 1.3.Age:(0 to 99) (Write) : } \\
\hline 1.4.Marital status: & \multicolumn{2}{|c|}{$\begin{array}{l}\text { 1. Married 2. Unmarried 3. Widowed } \\
\text { 5.Separated }\end{array}$} \\
\hline \multicolumn{3}{|l|}{ Section-2: Microfinance } \\
\hline \multicolumn{2}{|c|}{$\begin{array}{l}\text { 1. If Non-Borrower, then why? (Specify \& write) } \\
\text { 1. Not applicable } \\
\text { 2. Not necessary: } \\
\text { 3. Have alternative way } \\
\text { 4. High interest } \\
\text { 5. Cause of tension and huge pressure } \\
\text { 6. Inability to pay } \\
\text { 7. Religious prohibition of interest } \\
\text { 8. Need but not get } \\
\text { 9. High interest is burden; fear to be a defaulter } \\
\text { 10. Do not know about the MF program }\end{array}$} & $\begin{array}{ll}\text { 2. } & \text { What are the alternative sources of fi- } \\
\text { nance of non-borrowers: (insert } 0 \text {-if not } \\
\text { applicable) } \\
\text { 1. Private bank } \\
\text { 2. Govt. bank } \\
\text { 3. Local co-operative } \\
\text { 4. Job place } \\
\text { 5. } \\
\text { 6. Fovt. department } \\
\text { 7. Neighbour } \\
\text { 8. } \\
\text { 9. } & \text { Monative } \\
\end{array}$ \\
\hline \multicolumn{3}{|c|}{$\begin{array}{l}\text { 3. Are you interested in becoming a member of Islamic micro } \\
\text { 1. Don't know about Islamic microfinance } \\
\text { 2. Member of Islamic microfinance } \\
\text { 3. Interested if provide education, training, and interest free loan } \\
\text { 4. Not necessary }\end{array}$} \\
\hline \multicolumn{3}{|c|}{$\begin{array}{l}\text { 4. Any comment regarding microcredit, livelihood strategies, expenses in education and health care, etc.? } \\
\text { (Open Remarks) }\end{array}$} \\
\hline
\end{tabular}


1. Helpful

2. Need but not get loan

3. If provide training; then I will participate

4. Not helpful: High interest

5. Burden

6. No ability to repay the loan

7. Not so good; Not so bad

8. Amount of Money (to be paid) should be reduced in each instalment; OR Instalment should be increased

9. Helpful but interest rate should be reduced

10. I need loan and I will become member immediately

11. If interest is reduced; then I will participate again

12. Few opportunities for investment; high interest rate; and continuous instalments; if these are solved; then I will take

13. MFIs should provide training and interest free Loan

14. MFIs do not provide loan to extremely poor people. this is bad rule

15. No tenure security; hence no regular loan

16. Instalment should be done monthly instead of weekly

17. We need donation; training and job

18. We do not know saving interest rate

19. Others

Basharat Hossain is currently working as an Assistant professor (economics) at the Department of Business Administration, International Islamic University Chittagong, Bangladesh. Previously, he served as a junior research fellow at the Islamic Economics Research Bureau (IERB), Dhaka, Bangladesh. He obtained his Bachelor of social science (Honors) and Master of social science in economics from the department of economics, University of Dhaka, Bangladesh. He is also a candidate of Master of Philosophy (M.Phil.) at the same university. Throughout his education, he achieved outstanding grades earning him scholarships at all education levels. He has a unique focus on national economic issues and has published about twenty articles in national newspapers and magazines. His research interests include: public and monetary economics, development economics, economies of third world countries, and Islamic economics and finance. Many of his research articles have been published in internationally reputed academic journals. He has also participated and presented papers in six international conferences.

E-mail: basharatdu@gmail.com 


\title{
نموذج التمويل الأصغروإعادة التأهيل الإسلامي للأحياء الفقيرة والعائمة

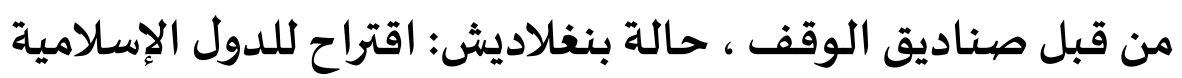

\author{
بشارت حسين \\ أستاذ مساعد في الاقتصاد ، قسم إدارة الأعمال \\ الجامعة الإسلامية الدولية شيتاغونغ (IIUC) ، بنغلاديش فيش الدفاد الدعال
}

المستخلص. هذه الورقة تقدم نموذجًا مفاهيميًا للتمويل الأصغر الإسلامي وإعادة التأهيل من خلال

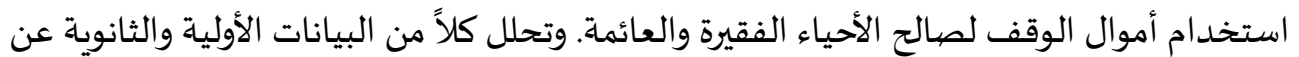

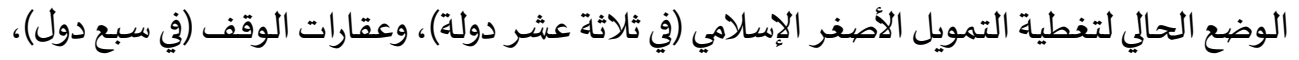

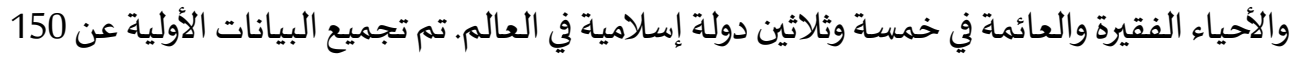

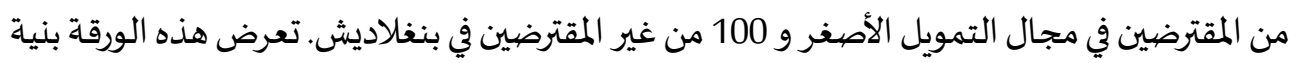

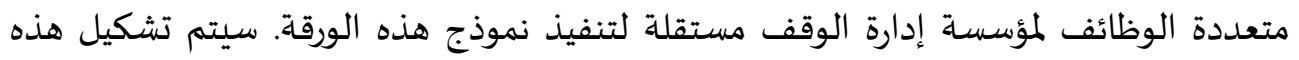
المؤسسة من خلال مشروع مشترك بين الحكومة والهيئات الإسلامية الوطنية والدولية. علاوة على ذلك، الكان.

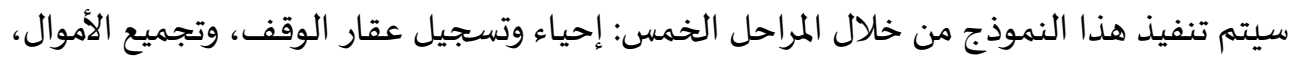

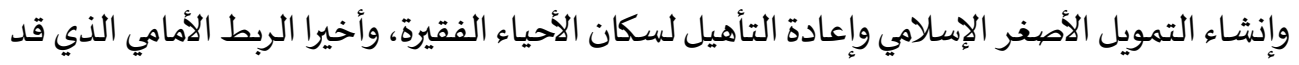
يساعد سكان الأحياء الفقيرة على المساهمة في المجتمع.

الكلمات الدَّالة: الوقف، التمويل الأصغر الإسلامي، إعادة التأهيل ، سكان الأحياء الفقيرة ، الدول

$$
\text { الإسلامية. }
$$

تصنيف S4 H15 E23 KAUJIE 